\title{
Political environment and foreign direct investment: evidence from OECD countries
}

\author{
Tomasz P. Wisniewski ${ }^{\mathrm{a} 1}$, Saima K. Pathan ${ }^{\mathrm{a}, \mathrm{b}}$ \\ ${ }^{a}$ School of Management, University of Leicester, Leicester, LE1 7RH, UK \\ ${ }^{\mathrm{b}}$ Institute of Business Administration, University of Sindh, Jamshoro-76080, Sindh, Pakistan
}

\begin{abstract}
This paper examines the role that political factors play in the investment location decisions of multinational enterprises. It has been found that foreign direct investors shy away from countries with excessive government spending, especially when this spending is directed towards the military. They also seem to have a slight preference for leftist executives and be negatively predisposed toward situations in which the ruling party has held power for prolonged periods of time. Ceteris paribus, more FDI flows to countries that have presidential systems, established political parties and where the party of the executive controls all houses with lawmaking powers.
\end{abstract}

JEL classifications: F21; F50; P16

Keywords: Foreign Direct Investment; Political Economy; MNEs; OECD

\footnotetext{
${ }^{1}$ Corresponding author. Phone: 0044116252 3958, E-mail: t.wisniewski@le.ac.uk.
} 


\section{Introduction}

Recent decades have witnessed great capital mobility and the opening of national borders. Large flows of foreign direct investments (FDI) are now a hallmark of the globalized economy and local policy-makers compete vigorously to attract long-term investments. FDI facilitate the transfer of technological innovations and carry the potential to foster economic growth and employment (Jensen, 2003). Compared to portfolio investments, they are characterized by lower volatility and are more likely to withstand sudden changes in market sentiment (Busse and Hefeker, 2007). In light of the possible benefits that can materialize as a result of FDI, it is important to understand the motivations that underlie the choices of investment locations made by multinational enterprises (MNEs). This paper attempts to deepen this understanding by assessing whether FDI flows are sensitive to the political environment of a host country.

The existing literature in this field focused primarily on the question of whether foreign investors have a preference for nations with democratically elected leaderships. Evidence that emerged can best be described as mixed. Oneal (1994) alluded to the possibility that a cooperation between autocratic governments and MNEs could be mutually beneficial, but found no statistically significant relationship between U.S. outward FDI flows and the political regimes of the recipient countries. Li and Resnick (2003) developed this logic further by arguing that, in exchange for bribes, autocrats could guarantee monopolistic or oligopolistic positions for foreign entrants, offer generous incentives and disregard the legitimate objections raised by local businesses. Corruption in such contexts may be thus viewed as a 'helping hand' that guides the process of overcoming numerous country-specific obstacles (Egger and Winner, 2005). MNEs headquartered in countries that explicitly prohibit bribery of foreign officials, however, may be reluctant to enter into these types of arrangements (Cuervo-Cazurra, 2006). It is mostly the corporations from other corrupt 
nations, with a wealth of experience in terms of navigating various bribery practices, that are likely to invest in such environments (Ledyaeva et al., 2013; Aleksynska and Havrylchyk, 2013). Practical difficulties of corruption aside, Li and Resnick (2003) present empirical results that seem to be consistent with the notion that the existence of democracy is a dissuading factor for foreign investors who prefer to engage with autocracies. However, in a follow-up study, Jakobsen and de Soysa (2006) demonstrated that Li and Resnick's findings are very sensitive to the sample selection and the choice of modeling approach.

On the other side of the debate, Jensen (2003) propounds two arguments explaining why democratic governments are perceived as more credible in the eyes of foreign capital owners. Firstly, the presence of veto players in the system contributes to the stability of political decision-making by limiting the possibility of sudden policy reversals. Secondly, democratic leaders may suffer a loss of electoral support should they choose to renege on their promises to international investors. This potential loss of support is referred to in the literature as the 'audience costs'. Using a large sample of countries, Jensen shows that ceteris paribus democratic countries tend to attract more inward FDI, which corroborates his reasoning. Jensen's predictions are in harmony with the findings of Harms and Ursprung (2002) who assert that inward FDIs tend to gravitate towards nations that respect civil and political liberties. Asiedu and Lien (2011) point out that democratic systems also provide checks and balances on leaders and typically strengthen property rights, which could possibly account for the observed positive nexus between democracy and inward FDI. They further note that this nexus breaks down for countries rich in natural resources, where other considerations may be paramount.

This paper focuses on the interaction between FDI in OECD countries and their political institutions and processes. Since the commitment to democratic processes in these nations is unwavering, applying the standard division into autocratic and democratic states in this 
particular case would not be very productive. Instead, the goal is to investigate more subtle differences in the political environments and to test whether they play an important role in the decisions of international investors. In what follows, it is documented that these nuanced variations do indeed make a significant difference to the geographical distribution of FDI. While much of the existing literature on the political economy of cross-border investments seems to be preoccupied exclusively with the characteristics of developing nations, it needs be pointed out that net FDI inflows to OECD countries between 2000 and 2010 accounted for $69.5 \%$ of all FDI worldwide (World Bank, 2011). The added benefit of considering industrialized nations is the greater availability of reliable statistical information.

The remainder of this paper is organized as follows. The next section reviews the extant literature and attempts to hypothesize a number of relationships between political factors and inward FDI. Section III describes data sources and provides summary statistics. Empirical analysis and interpretation of results are presented in Section IV, while Section V presents a battery of robustness checks. The paper ends by drawing some conclusions.

\section{Literature review and hypotheses development}

One of the variables that is, to a large extent, under the control of domestic policymakers is the total level of public spending. Fiscal policy can play an important role in determining future levels of inflation, interest rates and taxation (see for instance Sims, 1994; Laubach, 2009). Furthermore, excessive government consumption has been shown to slow down economic growth (Landau, 1983; Grier and Tullock, 1989; Barro, 1990; Henisz, 2000) and crowd out private investments (Argimón et al., 1997). With respect to FDI flows, the findings reported in Jensen (2003) and Choi and Samy (2008) suggest that the ability to

maintain a budgetary discipline is an important condition that needs to be met in order to effectively attract foreign direct capital. 
Not only does the current inquiry seek to re-affirm the conclusions of previous studies in a sample of developed countries, but it also engages in analyzing more disaggregated data. To a certain degree, this idea follows the logic presented in Oneal (1994), who hypothesized that investors may shy away from countries where the military controls the government. From the point of view of government spending, it is reasonable to argue that corporations operating internationally would be more alarmed by large military outlays, as opposed to other types of government expenditure. While MNEs could derive benefits from improved infrastructures or highly educated workforces, they are unlikely to gain much from international conflicts and warmongering. Consequently, the two following hypotheses will be investigated:

Hypothesis 1: FDI decreases with more government spending

Hypothesis 2: Military expenditure is a bigger deterrent to FDI inflows than other types of government consumption

It is also conceivable that foreign investors have specific preferences with regard to the political ideology of the executive. In his seminal paper, Hibbs (1977) argued that parties of various persuasions cater to the needs of their specific electorates, which has ramifications for macroeconomic outcomes. He documented that left-wing parties favor low unemploymenthigh inflation constellations, whereas the opposite is true for parties that lean to the right. Interestingly, the evidence shows that the decisions of U.S. stock market investors may be, in part, driven by their political predilections. Stock market returns, particularly on the small capitalization stocks, were shown to be much higher under Democratic than Republican administrations (Johnson et al., 1999; Santa-Clara and Valkanov, 2003). A profitable trading 
strategy that is able to take advantage of this curious stock market anomaly could have been easily designed (Hensel and Ziemba, 1995). ${ }^{2}$

In the context of FDI, Pinto and Pinto (2008) present a theoretical model which predicts partisan cycles in cross-border investments. More specifically, leftist governments are expected to encourage capital imports that complement labor in the production process, whereas right-wing incumbents back FDI that substitute for labor. Mudambi and Navarra (2003) examined empirically whether flows of FDI into different regions of Italy were a function of voters' electoral preferences. In light of their results, they argue that MNE investment location decisions are essentially a two-stage process. During the first stage international corporations primarily consider the firm- and location-specific variables, whereas the regional political tradition appears to matter only incrementally, once the firststage considerations are fully accounted for.

While two previous studies examined the impact of the political orientation of the executive in a multi-country setting, there appears to be a lack of consensus with regard to its importance. Schneider and Frey (1985) presented a model, which linked FDI inflows to a binary variable for a leftist executive, but the relationship proved to be statistically insignificant. In a more recent examination, Jakobsen and de Soysa (2006) used a similar measure and found a strong positive influence, indicating that pro-labor governments may welcome FDI due to their potential to reduce unemployment. The current investigation employs a different classification of political ideology compared to that used in Schneider and Frey (1985) and Jakobsen and de Soysa (2006). Instead of relying on the traditional dichotomy, the political spectrum is divided here into right, left and center. As will be demonstrated, this rather minor change in measurement helps to uncover rather interesting

\footnotetext{
${ }^{2}$ Cahan et al. (2005) and Bohl and Gottschalk (2006) examine whether political orientation of the ruling party determines stock returns in countries other than the U.S..
} 
empirical regularities. In light of the foregoing discussion the following hypothesis is put forward:

\section{Hypothesis 3: FDI inflows are a function of the political orientation of the executive}

The system of government can be used to differentiate between the countries under investigation. For instance, South Korea and the United States operate a presidential system, while most of the European nations have adopted a parliamentary form of government. The key feature of presidential systems is the separation of powers doctrine, with the executive and legislature being elected independently. An advantage of such an arrangement is the fact that these two branches of government can monitor each other's actions and that the executive is chosen directly by the voters. In contrast, parliamentary systems have an executive who is elected by the legislature and who may not enjoy a fixed term. Due to a number of circumstances, elections may be called early (Cargill and Hutchison, 1991; Bialkowski et al., 2008), which exacerbates the political risk. Executives may also get entangled in complex coalition maneuvering, which could complicate the task of implementing their party manifesto. On the other hand, parliamentary systems do not necessarily suffer from the 'winner takes it all' characteristic, which means that they could be more ideologically embracive.

Since both systems have their unique strengths and weaknesses, it is difficult to predict $a$ priori their implications for FDI. The task of uncovering investors' preferences in this matter becomes a purely empirical exercise. Unfortunately, the existing literature does not give any indications on what relationship to expect. In order to shed more light on this issue, the following hypothesis is tested:

Hypothesis 4: When choosing FDI location, MNEs are not indifferent to the system of government 
Another aspect that warrants closer examination is the number of years that the party of the executive stayed in office. In the OECD sample, this variable takes on particularly high values in Hungary, the Czech Republic and Poland prior to the fall of communism and in Mexico before 2000, indicating that it is a good proxy for the lack of political competition. An environment in which voters are not able to fully express their political preferences and hold incumbents accountable for their actions is not conducive to economic development. Using panel data from US states, Besley et al. (2010) show that weak political competition is a serious hindrance to economic prosperity. It may also affect the reputation of a country in the international arena. This leads to the formulation of the following hypothesis:

Hypothesis 5: Inward FDI is inversely related to the length of time that the party of the executive has stayed in office

As has been mentioned earlier, the literature offers a lively debate centered on the role of democracy in cross-border investment decisions by MNEs (Harms and Ursprung, 2002; Li and Resnick, 2003; Jensen, 2003; Asiedu and Lien, 2011). It needs to be pointed out, however, that all of the OECD countries included in our sample can be considered democratic. Instead, a more appropriate question to ask would be how established these democracies are. In order to quantify the political heritage of a nation we collect information on the average ages of the largest parties. High values recorded by this gauge would attest to the wealth of democratic tradition and would indicate that mainstream parties are wellentrenched. This, in turn, implies a lower probability that political fringe groups will rise to power. In a climate of political stability, MNEs can apply lower discount rates at the project appraisal stage, which would generate higher investments levels. These considerations motivate the next hypothesis:

Hypothesis 6: The average age of the main parties in democratic countries is positively related to FDI 
Finally, there remains the question of whether the executive can effectively implement the desired policy changes. An executive's efforts could be potentially frustrated by political gridlock causing a prolonged impasse. If international investors prefer decisiveness, they will shy away from countries where the likelihood of political deadlock is higher. To control for this eventuality within the empirical model presented here, an additional dummy variable is incorporated as a regressor. It takes a value of one when the party of the executive has an absolute majority in all relevant houses and zero otherwise. Its postulated relationship with FDI can be formalized as follows:

Hypothesis 7: Ceteris paribus, MNEs direct more FDI to countries where the party of executive controls all houses with lawmaking powers

\section{Data}

The dataset used in this study spans a period from 1975 to 2009 and comprises 33 OECD members. The only OECD country not included in our sample was Luxembourg, as it was an extreme outlier in the sample. This is a likely result of the FDI statistics being significantly distorted by capital in transit through Special Purpose Entities domiciled in this country (OECD , 2008). ${ }^{3}$ This paper focuses entirely on the post-Bretton Woods era, a timeframe in which capital movements were relatively unrestricted by government regulation. A number of sources have been utilized in order to collect the statistical data, including World Development Indicators (World Bank, 2011), Main Economic Indicators (OECD, 2011), and Database of Political Institutions 2010 (Beck et al., 2001). The variables constructed based on these sources are listed in Table I along with their exact definitions.

\section{[Insert Table I about here]}

\footnotetext{
${ }^{3}$ The average net FDI inflow to Luxembourg averaged to $146.08 \%$ of GDP during the sample period, compared to $2.54 \%$ for other OECD members. Some previous studies and datasets have combined the FDI data for Luxembourg and Belgium into one series (see for instance Head and Ries (2008)). This paper however excludes Luxembourg, as it is feared that capital in transit may have been misclassified as genuine FDI.
} 
Following Jensen (2003) and Ahlquist (2006), we define our dependent variable as net FDI inflows expressed as a percentage of GDP. The process of scaling by GDP leads to a stationary series, which is of great importance for the validity of statistical inferences. The Levin, Lin and Chu (2002) panel unit root test which assumes a common autoregressive structure across cross-sections has been applied to the FDI_Inflow variable and has rejected the null hypothesis of a common unit root. Similarly, the results of Fisher-type ADF and PP tests (Maddala and Wu, 1999; Choi, 2001) did not indicate the presence of individual unit root processes. ${ }^{4}$ Given the absence of stochastic trends, this specification of the dependent variable is superior to other possible alternatives.

Not only does Table I enumerate the political measures that are essential for the testing of the hypotheses, but it also catalogues the control variables. As it is customary in the literature (see for instance Busse and Hefeker, 2007), we control for trade openness, defined as the sum of imports and exports scaled by GDP. Furthermore, a measure of economic growth is included to account for the fact that FDI are likely to be procyclical. The variable Inflation is intended to capture the lack of monetary discipline within the country. In light of the findings reported in Bengoa and Sanchez-Robles (2003) for Latin America, one would expect a negative inflation-FDI relationship.

[Insert Table II about here]

Table II reports the summary statistics for the variables used in the study. The average level of FDI net inflows, computed over all sample countries and years, equaled $2.54 \%$ of GDP. About $12 \%$ of total government consumption expenditure was earmarked for military. It needs to be noted that data for the military expenditure variable is available only from 1988 onwards, which results in a reduced number of observations. Furthermore, Table II indicates

\footnotetext{
${ }^{4}$ Detailed test results are available from authors upon request.
} 
that in $46 \%$ of cases the party of the executive was either conservative, Christian democratic, or right-wing, while the centrist executives were significantly less common. The means of Party_Age and Presidential attest to the fact that the sample comprises primarily wellestablished democracies, among which parliamentary systems tended to be most prevalent. On average, parties of the executive stayed in power for about nine years. The nine-year mean, however, was influenced by high values recorded in countries of Eastern Europe before the fall of communism and in Mexico prior to 2000. Finally, parties of the executives frequently did not control all houses with lawmaking powers.

An important question that can be asked at this stage is whether the correlations between explanatory variables are high enough to induce multicollinearity problems. We present the correlation coefficients between our regressors in Appendix AI. As can be seen from the table, most of the correlation coefficients are sufficiently low, with the exception of the Government_Spending and Non-Military_Expenditure nexus. These two variables, however, are never bundled together in a single specification bypassing therefore a potential econometric problem. We have also calculated variance inflation factors (VIFs) for our pooled regressions. Although there is no well-defined cut-off point for the VIFs, Chatterjee and Price (1991) suggest that values in the region of 10 may be an indication of problems. All of the VIFs in our regressions fall comfortably below this threshold indicating that multicollinearity is not present.

\section{Empirical results}

This paper adopts several approaches to modeling the FDI flows. The first method employed is the pooled OLS estimation. Since the Breusch-Pagan-Godfrey tests (Breusch and Pagan, 1979; Godfrey, 1978) reject the null hypotheses of homoskedasticity, we use White 
(1980) heteroskedasticity-consistent standard errors. ${ }^{5}$ The following regression equation is fitted to the underlying data:

$$
\begin{aligned}
\text { FDI_Inflow }_{i, t} & =\beta_{0}+\beta_{1} \text { Government_Spending }_{i, t}+\beta_{2} \text { Right }_{i, t}+\beta_{3} \text { Left }_{i, t} \\
& +\beta_{4} \text { Presidential }_{i}+\beta_{5} \text { Years_In_Power }_{i, t}+\beta_{6} \text { Party_Age }_{i, t} \\
& +\beta_{7} \text { All_Houses }_{i, t}+\beta_{8} \text { Openness }_{i, t}+\beta_{9} \text { GDP_Growt }_{i, t} \\
& +\beta_{10} \text { Inflation }_{i, t}+\varepsilon_{i, t}
\end{aligned}
$$

The definitions of the variables appearing in this equation can be found in Table I. A second version of this regression is estimated with the government spending variable being split into two components, namely Military_Expenditure and Non-Military_Expenditure.

The next modeling approach adopted here is the fixed effect panel. Fixed effect panel models are likely to be superior on theoretical grounds, as they control for time-invariant heterogeneity across countries and are relatively robust to omitted variable bias (Chamberlain, 1978; Hausman and Taylor, 1981). Pooled OLS models can however be effectively used to evaluate the robustness of the results. The results of Hausman (1978) tests indicate that the random effect model may be inconsistent and that assuming the existence of fixed effects is the preferred alternative. ${ }^{6}$ Moreover, the hypothesis of redundant fixed effects is strongly rejected, providing further justification for the modeling approach employed here. Since the Presidential variable is time invariant, it has to be excluded from the panel estimation, as it is perfectly collinear with the fixed effects. As a result the equation to be fitted becomes:

\footnotetext{
${ }^{5}$ The $p$-values for the null of homoskedasticity in regressions (1) and (2) reported in Table III are 0.0067 and 0.0433 , respectively.

${ }^{6}$ The $p$-values for the null hypothesis that the random effects and regressors are orthogonal in fixed effect models (3) and (4) reported in Table III are 0.0018 and 0.0006, respectively.
} 


$$
\begin{aligned}
\text { FDI_Inflow }_{i, t} & =\beta_{0, i}+\beta_{1} \text { Government_Spending }_{i, t}+\beta_{2} \text { Right }_{i, t}+\beta_{3} \text { Left }_{i, t} \\
& +\beta_{4} \text { Years_In_Power }_{i, t}+\beta_{5} \text { Party_Age }_{i, t}+\beta_{6} \text { All_Houses }_{i, t} \\
& +\beta_{7} \text { Openness }_{i, t}+\beta_{8} \text { GDP_Growth }_{i, t}+\beta_{9} \text { Inflation }_{i, t} \\
& +\sum_{j=t 1}^{T-1} \gamma_{j} \text { Year_Dummy }_{-} j_{t}+\varepsilon_{i, t}
\end{aligned}
$$

where $\beta_{0, i}$ is the country-specific intercept, $t 1$ is the year marking the starting date of our sample, $T$ is the last year in the sample, Year_Dummy $j$ is an indicator variable taking a value of one in year $j$ and zero otherwise, and where $\varepsilon$ is the random error.

The equation above is first fitted using Estimated GLS (EGLS) method with crosssection weights and restricts all $\gamma_{j}$ to zero. The second estimation allows for year-specific dummies, which means that the model becomes a two-way fixed effect panel. No weighting is applied in the second approach. Again, two versions of the equation are fitted under each estimation method, one where government spending is aggregated and one in which it is decomposed into two items.

[Insert Table III about here]

The estimated coefficients and their corresponding significance levels shown in Table III paint a picture of strong influence of political factors on FDI. Firstly, the size of government has a negative impact on the FDI inflows, presumably due to its implications for the general level of taxation. In that our results appear to be consistent with the earlier findings of Jensen (2003) and Choi and Samy (2008). At the same time, it needs to be noted that international investors do not perceive all types of government spending to be equally detrimental. The absolute value of the coefficient on military expenditure is typically about three times larger than that on other types of spending. From the point of view of MNEs, tax proceeds seem to 
be best utilized when directed into productive types of activities, which yield positive externalities to investors and the country in general.

When interpreting the value of slopes on Right and Center dummy variables, one needs to bear in mind that a leftist orientation of the executive is taken as a benchmark. The coefficients on the Center variable are consistently negative and statistically significant in three specifications. Pinto and Pinto (2008) have shown that pro-labor governments prefer foreign investments that increase employment, while pro-capital governments encourage capital imports that substitute for labor. The role of centrist parties is less apparent and one may argue that, in the absence of a clearly defined directional ideology, political decisions become less predictable. This notion of increased risk coheres with the observed empirical results. Furthermore, it is noteworthy that in the two-way fixed effect panel specification the Right dummy bears a negative coefficient and is statistically significant. Here, our findings are consistent with Jakobsen and de Soysa (2006) who argue "Leftist governments among democracies, $[\ldots]$ are inclined to prefer FDI due to the implications for labor from capital imports". Such assertion bears some resemblance to the observations of Santa-Clara and Valkanov (2003) who claim that stock market returns in the U.S. were much higher under Democratic than Republican administrations. From the estimates presented in Table III one can infer that, when contemplating their investment location decisions, MNEs have a slight preference for parties located towards the left of the political spectrum.

Unlike in the pooled OLS regressions, which control for the type of government system, the panel regressions do not incorporate the Presidential variable, as it is likely to be highly collinear with the fixed effects. Everything else being equal, countries with presidential systems seem to attract over $0.7 \%$ of GDP more FDI compared to those with parliamentary systems. This finding is significant at $1 \%$ level in the first specification in Table III and at 5\% level in the second regression. It is plausible that MNEs have a preference for the separation 
of power doctrine and an arrangement in which the executive and legislative branches scrutinize each other's actions. Furthermore, the lack of necessity to analyze complex coalition politics is an added benefit of the presidential system.

The evidence with respect to the Years_In_Power measure, which proxies for the lack of political competition within the country, is rather compelling. Its relationship with net FDI inflows is negative in all models and the null hypothesis of no association is rejected in five out of six cases. Political competition may be viewed as a requisite of an investment-friendly environment and a mechanism through which abuses of power are restrained. Our findings therefore conform to intuitive predictions and imply that healthy democratic processes are critical for a country's international reputation.

This conclusion is further strengthened by the observation that FDI tend to gravitate towards countries with well-established democratic systems. The average age of the main parties is a robust predictor in all regressions, showing significance at $1 \%$ level in most specifications. For each decade of experience that the parties have on average, the annual FDI inflows increase by over $0.1 \%$ of GDP. A political arena that comprises parties with long traditions is more stable for at least two reasons. First of all, it is unlikely that factions expressing radical views will be able to dominate political life. Secondly, smaller informational asymmetries reduce the risk even further, leading to higher levels of investment.

International investors also appear to have a high regard for decisiveness in political decision-making. A situation in which the party of the executive has control over all houses with lawmaking powers appears to be the favored scenario. It removes the possibility of prolonged gridlocks and accelerates the implementation of relevant policies. Unsurprisingly, the coefficients on All_Houses are always positive and statistically significant in the majority of specifications. 
Last but not least, the signs of the coefficients on the control variables conform to $a$ priori predictions in almost all of the cases. The most robust relationship to emerge is that between openness and FDI. Given the reported estimates, trade and cross-border direct investments should be viewed as complements, rather than substitutes (for a more detailed discussion on this issue please see Mundell (1957) and Markusen (1983)). FDI activity also tends to intensify somewhat during boom years and periods of low inflation.

Taken together, our results strongly indicate that the explanatory variables have the power to determine net FDI flows, as the $p$-values associated with the F-statistics for the regressions are indistinguishable from zero. Similarly, the $p$-values for the null hypothesis that political regressors do not jointly influence the inward FDI flows fall below the conventional significance levels, indicating that international investors do not ignore the political environment. The hypothesis of redundant fixed effects is universally rejected, thus supporting our choice of modeling approach. It is also worth noting that, depending on the particular specification and methodology, we are able to explain between $16 \%$ and $40 \%$ of variance of the dependent variable. Finally, and perhaps most importantly, all of the postulated theoretical hypotheses have found some confirmation in the data.

Although nowadays the OECD countries included in our sample can be considered a beacon of democracy, this has not always been the case throughout our sample period. To a certain extent, this fact can contaminate some of our interpretations. For instance, under a communist regime, the ruling party may be well-established and old, which will result in a high value of the Party_Age variable. However, this indicator was designed to measure the richness of democratic tradition. To avoid any potential interpretational difficulties, we have identified periods of 'inhibited democracy' within our sample countries and subsequently excluded these periods from our estimation. 
In our revised sample, the data for the post-communist countries of Estonia, Hungary, Poland and Slovenia starts in the years marking the first parliamentary elections after the fall of communism. The records for the Czech Republic and the Slovak Republic start in 1993, after the dissolution of Czechoslovakia. Since the first democratic elections in Chile after ousting Pinochet took place in 1989 , the information prior to that date is discarded. For the Republic of Korea we only include data for the Sixth Republic and for Turkey we exclude the period between 1980-1982. This period of the Turkish history started with coup d'état and was marked by martial law, abolition of Parliament and rule of the National Security Council. For Mexico, many observers consider the year 2000 as the start of true democracy, as it is the year in which the presidential power was passed peacefully to the opposition party following general elections; an unprecedented event. Following this reasoning, we exclude all Mexican data prior to 2000. Finally, the records for Spain begin in 1977, the date of first general elections after the death of Francisco Franco.

It is encouraging to note that not many observations were lost due to this data filtering exercise. In fact, the World Bank datasets we use already had a lot of missing values for autocracies, presumably because the official statistics produced by these systems are unreliable. The regression results based on the purely democratic sample are reported in Table IV. Broadly speaking, all of the conclusions derived from our earlier regressions are supported in the restricted sample. The only difference appears to be the attenuated explanatory power of the Right dummy variable in the two-way fixed effect specification, which has been previously significant at $10 \%$.

[Insert Table IV about here] 


\section{Robustness checks and further considerations}

In our empirical specifications we have experimented with another political variable, namely an elections dummy taking a value of one in the years when the general public casts their votes. In constructing the indicator we focused on presidential elections in countries with presidential systems and on parliamentary elections in nations with a parliamentary system of government. The data has been sourced from IDEA Voter Turnout Database (IDEA, 2011), Election Guide (IFES, 2011) and the Institutions and Elections Project Database (Regan et al., 2009). The impact of this particular variable on FDI, however, is difficult to predict a priori on theoretical grounds. The aspiration of incumbents to boost their pre-election ratings by welcoming more foreign direct capital contrasts strongly with the desire of MNEs to minimize their political risks. In an earlier paper, Julio and Yook (2012) show that the total capital expenditure of companies is diminished in election years. On the other hand, one may argue that FDI decisions are motivated by long-term considerations and therefore are unlikely to be influenced by ephemeral spikes in political uncertainty. We have found that the elections indicator was consistently insignificant and had little explanatory power.

We have also contemplated other control variables in our empirical modeling. Attempts have been made to measure the quality of infrastructure, although very few of the infrastructure indicators have records available consistently from 1975. A variable, measuring telephone lines per 100 people, from the World Development Indicators database has been used as a proxy. In our regressions, this infrastructure proxy was statistically significant, bore a positive coefficient and its inclusion did not change any of the conclusions reached. However, as one would expect with most infrastructure quality indicators, the number of phone lines was highly correlated with the non-military government expenditure, leading to multicollinearity problems. For this reason, we have decided to exclude this variable from our 
analysis. Similar problems were encountered when we controlled for the size of the market by incorporating either a natural logarithm of GDP or a total population. Strong correlations were observed with other regressors leading to excessive variance inflation factors. It is interesting to note that while adding these variables is likely to lead to econometric problems, it does not change any inferences regarding our hypotheses outlined earlier.

One may argue also that endogenity may be present in the model and that some of the regressors should be lagged. It is not sensible, however, to pre-suppose a bi-directional feedback between all of the variables and FDI. For instance, the presence of international investors may change governments' spending patterns or their willingness to get involved in international conflicts. It is also possible that FDI inflows exert some influence over the voting intentions of the general public. A reverse causality between FDI and macroeconomic aggregates is likewise easy to imagine. On the other hand, it does not make sense to argue that FDIs can force the country to switch between presidential and parliamentary systems, that they will affect the age of the political parties, change the duration of tenure of incumbents or determine whether the party of the executive controls all houses with lawmaking powers. We estimated a regression specification that lags all of the regressors for which endogeneity could be reasonably suspected and noted that all of our earlier conclusions were re-confirmed.

Another version of fixed effect panel regression has been tried where cumulative three-year FDI for non-overlapping periods was regressed against three-year averages of independent variables. Such approach smoothes the underlying data, but also dramatically reduces the number of degrees of freedom. Despite the small sample problem, the relevant political variables still exhibited some degree of statistical significance. Another noteworthy observation was that the R-squared measure has increased dramatically, which presumably 
can be attributed to the fact that averaging and summing eliminates a lot of short-lived noise from the data.

The empirical models presented in this paper have also been fitted in different subsamples. Firstly, we want to note that the regressions incorporating Military_Expenditure and Non-Military_Expenditure are based on a sample starting in 1988 which is dictated by data availability, while all the remaining models utilize information from 1975. Additionally, we have estimated a regression with data running only up to 2007 and in doing so, we were able to eliminate the influence of the recent financial crisis. Finally, we recalculated the regressions for a sample that excludes post-communist countries, namely Czech Republic, Estonia, Hungary, Poland, Slovak Republic, Slovenia (see Appendix AII for more details). These exercises clearly documented that our conclusions are not a by-product of the recent financial crisis, nor are they driven solely by the major political transitions in the postsocialist economies.

Finally, we have experimented with clustered standard errors in our pooled OLS estimation. Standard errors could potentially cluster by cross-sectional units (countries) or time (Thomson, 2011) and we implemented both approaches. As it is always the case with this type of methodological approach, the point estimates of coefficients remain the same compared with a simple OLS and it is only the standard errors of the parameters that change. Unsurprisingly, therefore, the sign of all coefficient estimates remained unaltered. Importantly, all of the political variables retained their statistical significance in at least one of the implemented regressions, with the exception of the All_Houses indicator.

\section{Conclusions}

By focusing on the post-Bretton Woods period, this paper has endeavored to examine the political economy of FDI. While the previous literature devoted much attention to the nexus 
between cross-border investments and the existence of democracy, our goal was to analyze more subtle aspects of political life. Since the sample includes only OECD countries, all of which are currently fully democratic, the differentiation between their political environments had to be, by design, more nuanced and multidimensional. In other words, ours is a study that attempts to address the empirical lacuna with respect to how the finer aspects of political systems impact on inward FDI flows. In doing so, we arrive at a realization that political factors strongly affect the investment location decisions made by MNEs.

Bloated government spending appeared to impede inflows of FDI, especially when this spending was channeled towards the military. Foreign investors, in aggregate, showed favoritism toward left-wing executives and tended to discriminate weakly against right-wing leaders and strongly against centrists. It is conceivable that the actions of centrists are less predictable and that they need to signal their future policies more credibly. Similarly, the task of forecasting the decisions of coalition governments may be rather thorny and investors seemed to have a slight predilection for presidential systems.

A prolonged stay in power by a single party was negatively related to direct investments, as it is symptomatic of a lack of effective political competition. FDI also had a tendency to flow more abundantly into countries with long tradition of democracy. When the main parties in the country have a far-reaching history, the informational asymmetries and related investment risks are reduced. Finally, investors showed a preference for decisiveness in policy making. When the party of the executive holds a majority in all houses with lawmaking powers, the necessary reforms can be implemented in a more expeditious way.

These results highlight the fact that removing political uncertainty is an essential ingredient in fostering an investment-friendly climate. Several self-evident recommendations can be offered at this stage. In order to attract foreign direct investors, governments have to restrain their expenditure and abstain from warmongering. A clear statement of an 
executive's future intentions, combined with a tendency to deliver on the promises made, could further diffuse political uncertainty. Moreover, cultivating democratic traditions and ensuring continuous competition in the political arena can increase the international appeal of a country as an investment destination. Finally, it is productive to avoid situations in which the responsibility for political decision-making is diffused and those which are conducive to political gridlocks.

\section{Acknowledgements}

We would like to thank the editor and two anonymous referees for their helpful suggestions and guidance. Tomasz Piotr Wisniewski would like to acknowledge the support of the University of Leicester's sabbatical scheme. 


\section{Appendix AI}

\section{Pearson Correlation Coefficients between Explanatory Variables}

\begin{tabular}{|c|c|c|c|c|c|c|c|c|c|c|c|}
\hline & $\begin{array}{l}\text { Government } \\
\text { Spending }\end{array}$ & $\begin{array}{c}\text { Military } \\
\text { Expenditure }\end{array}$ & $\begin{array}{c}\text { Non- } \\
\text { Military } \\
\text { Expenditure }\end{array}$ & Right & Center & Presidential & $\begin{array}{c}\text { Years_In } \\
\text { Power }\end{array}$ & Party_Age & All_Houses & Openness & $\begin{array}{c}\text { GDP } \\
\text { Growth }\end{array}$ \\
\hline Government_Spending & 1.0000 & & & & & & & & & & \\
\hline Military_Expenditure & 0.2452 & 1.0000 & & & & & & & & & \\
\hline Non-Military_Expenditure & 0.9172 & -0.1613 & 1.0000 & & & & & & & & \\
\hline Right & 0.0493 & 0.1959 & -0.0303 & 1.0000 & & & & & & & \\
\hline Center & -0.1655 & -0.1749 & -0.0966 & -0.3424 & 1.0000 & & & & & & \\
\hline Presidential & -0.4528 & 0.1595 & -0.5265 & 0.0764 & 0.0019 & 1.0000 & & & & & \\
\hline Years_In_Power & -0.2938 & -0.2282 & -0.2053 & -0.1055 & 0.0629 & 0.2290 & 1.0000 & & & & \\
\hline Party_Age & 0.1573 & -0.1049 & 0.2032 & -0.0203 & 0.0468 & -0.0286 & 0.0429 & 1.0000 & & & \\
\hline All_Houses & -0.3090 & 0.0828 & -0.3486 & 0.0599 & -0.1322 & 0.2507 & 0.1551 & -0.0944 & 1.0000 & & \\
\hline Openness & 0.1206 & -0.2278 & 0.2163 & -0.2051 & 0.4186 & -0.2276 & 0.0669 & -0.0459 & -0.2687 & 1.0000 & \\
\hline GDP_Growth & -0.2221 & -0.0143 & -0.2202 & -0.1405 & 0.1146 & 0.0733 & 0.0003 & -0.1213 & 0.0321 & 0.2099 & 1.0000 \\
\hline Inflation & -0.2682 & 0.1505 & -0.3349 & 0.0711 & -0.0850 & 0.0338 & 0.0834 & -0.2319 & 0.0680 & -0.0979 & -0.0821 \\
\hline
\end{tabular}




\section{Appendix AII}

\section{Models Based on a Sample Excluding Post-Communist Countries}

The post-communist countries of the Eastern and Central Europe (Czech Republic, Estonia, Hungary, Poland, Slovak Republic, Slovenia) were excluded from our initial, complete sample. Based on this restricted dataset, the regressions linking FDI_Inflow with a range of explanatory and control variables were estimated and the results are reported in the table below. Exact definitions of the variables appearing in the regressions can be found in Table I. Models (1) and (2) use a pooled OLS estimation technique with White (1980) heteroskedasticity-consistent standard errors, while models (3) and (4) estimate a fixed effect model by the means of a feasible GLS method with cross-section weights. Standard errors are given in parentheses. ${ }^{* * *},{ }^{* *},{ }^{*}$ denote statistical significance at $1 \%, 5 \%$ and $10 \%$, respectively.

\section{Pooled OLS}

(1)

\begin{tabular}{|c|c|c|c|c|}
\hline Intercept & $\begin{array}{l}-0.8238 \\
(0.6277)\end{array}$ & $\begin{array}{l}-1.5824 \\
(1.2509)\end{array}$ & & \\
\hline Government_Spending & $\begin{array}{l}-0.1044^{* *} \\
(0.0453)\end{array}$ & & $\begin{array}{l}-0.1486^{* * *} \\
(0.0308)\end{array}$ & \\
\hline Military_Expenditure & & $\begin{array}{l}-0.2790^{* * *} \\
(0.0760)\end{array}$ & & $\begin{array}{l}-0.6975^{* * *} \\
(0.0989)\end{array}$ \\
\hline Non-Military_Expenditure & & $\begin{array}{l}-0.0535 \\
(0.0766)\end{array}$ & & $\begin{array}{l}-0.2960^{* * *} \\
(0.0495)\end{array}$ \\
\hline Right & $\begin{array}{c}-0.1816 \\
(0.2530)\end{array}$ & $\begin{array}{c}-0.0932 \\
(0.3878)\end{array}$ & $\begin{array}{l}-0.0448 \\
(0.1049)\end{array}$ & $\begin{array}{l}-0.0602 \\
(0.1371)\end{array}$ \\
\hline Center & $\begin{array}{c}-1.2961^{*} \\
(0.6668)\end{array}$ & $\begin{array}{l}-3.3115^{* * *} \\
(0.9315)\end{array}$ & $\begin{array}{l}-0.3175^{* *} \\
(0.1465)\end{array}$ & $\begin{array}{c}-0.4648^{*} \\
(0.2543)\end{array}$ \\
\hline Presidential & $\begin{array}{c}0.6464^{* *} \\
(0.2893)\end{array}$ & $\begin{array}{c}1.0338^{*} \\
(0.5730)\end{array}$ & & \\
\hline Years_In_Power & $\begin{array}{l}-0.0133 \\
(0.0084)\end{array}$ & $\begin{array}{l}-0.0480^{* * *} \\
(0.0160)\end{array}$ & $\begin{array}{l}-0.0113^{* * *} \\
(0.0042)\end{array}$ & $\begin{array}{l}-0.0207^{* * *} \\
(0.0067)\end{array}$ \\
\hline Party_Age & $\begin{array}{l}0.0091^{* * * *} \\
(0.0033)\end{array}$ & $\begin{array}{c}0.0058 \\
(0.0040)\end{array}$ & $\begin{array}{c}0.0112^{* * *} \\
(0.0028)\end{array}$ & $\begin{array}{l}0.0128^{* * *} \\
(0.0039)\end{array}$ \\
\hline All_Houses & $\begin{array}{l}0.4468^{* * *} \\
(0.1604)\end{array}$ & $\begin{array}{c}0.5063^{* *} \\
(0.2380)\end{array}$ & $\begin{array}{c}0.0662 \\
(0.1124)\end{array}$ & $\begin{array}{c}0.1956 \\
(0.1417)\end{array}$ \\
\hline Openness & $\begin{array}{l}0.0744^{* * *} \\
(0.0155)\end{array}$ & $\begin{array}{l}0.0909^{* * *} \\
(0.0198)\end{array}$ & $\begin{array}{l}0.0786^{* * *} \\
(0.0075)\end{array}$ & $\begin{array}{l}0.0677^{* * *} \\
(0.0097)\end{array}$ \\
\hline GDP_Growth & $\begin{array}{c}0.0299 \\
(0.0469)\end{array}$ & $\begin{array}{c}0.0921 \\
(0.0709)\end{array}$ & $\begin{array}{l}-0.0090 \\
(0.0163)\end{array}$ & $\begin{array}{l}-0.0029 \\
(0.0214)\end{array}$ \\
\hline Inflation & $\begin{array}{l}-0.0140^{* * * *} \\
(0.0036)\end{array}$ & $\begin{array}{l}-0.0012 \\
(0.0092)\end{array}$ & $\begin{array}{l}-0.0138^{* * *} \\
(0.0037)\end{array}$ & $\begin{array}{l}-0.0039 \\
(0.0063)\end{array}$ \\
\hline Number of Observations & 823 & 531 & 823 & 531 \\
\hline R-squared (non-weighted) & 0.1587 & 0.2094 & 0.2336 & 0.3015 \\
\hline
\end{tabular}




\section{References}

Ahlquist, J.S., 2006. Economic policy, institutions, and capital flows: Portfolio and direct investment flows in developing countries. International Studies Quarterly 50, 681-704.

Aleksynska, M., Havrylchyk, O., 2013. FDI from the south: The role of institutional distance and natural resources. European Journal of Political Economy 29, 38-53.

Argimón, I., González-Páramo, J.M., Roldán, J.M., 1997. Evidence of public spending crowding-out from a panel of OECD countries. Applied Economics 29, 1001-1010.

Asiedu, E., Lien, D., 2011. Democracy, foreign direct investments and natural resources. Journal of International Economics 84, 99-111.

Barro, R.J., 1990. Government spending in a simple model of endogenous growth. Journal of Political Economy 98, 103-126.

Beck, T., Clarke, G., Groff, A., Keefer, P., Walsh, P., 2001. New tools in comparative political economy: The database of political institutions. World Bank Economic Review 15, 165-176.

Bengoa, M., Sanchez-Robles, B., 2003. Foreign direct investment, economic freedom and growth: New evidence from Latin America. European Journal of Political Economy 19, 529-545.

Besley, T., Persson, T., Sturm, D.M., 2010. Political competition, policy and growth: Theory and evidence from the US. Review of Economic Studies 77, 1329-1352.

Bialkowski, J., Gottschalk, K., Wisniewski, T.P., 2008. Stock market volatility around national elections. Journal of Banking and Finance 32, 1941-1953.

Bohl, M.T., Gottschalk, K., 2006. International evidence on the democrat premium and the presidential cycle effect, North American Journal of Economics and Finance 17, 107120.

Breusch, T.S., Pagan, A.R., 1979. A simple test for heteroskedasticity and random coefficient variation. Econometrica 48, 1287-1294.

Busse, M., Hefeker, C., 2007. Political risk, institutions and foreign direct investment. European Journal of Political Economy 23, 397-415.

Cahan, J., Malone, C.B., Powell, J.G., Choti, U.W., 2005. Stock market political cycles in a small, two-party democracy, Applied Economics Letters 12, 735-40.

Cargill, T.F., Hutchison, M.M., 1991. Political business cycles with endogenous election timing: Evidence from Japan. Review of Economics and Statistics 73, 733-739.

Chamberlain, G., 1978. Omitted variable bias in panel data: Estimating the returns to schooling. Annales de L'Insee 30-31, 49-82.

Chatterjee, S., Price, B., 1991. Regression Diagnostics. John Wiley, New York. 
Choi, I., 2001. Unit root tests for panel data. Journal of International Money and Finance 20, 249-272.

Choi, S.W., Samy, Y., 2008. Reexamining the effects of democratic institutions on inflows of foreign direct investment in developing countries. Foreign Policy Analysis 4, 83-103.

Cuervo-Cazurra, A., 2006. Who cares about corruption? Journal of International Business Studies 37, 807-822.

Egger, P., Winner, H., 2005. Evidence on corruption as an incentive for foreign direct investment. European Journal of Political Economy 21, 932-952.

Godfrey, L.G., 1978. Testing for multiplicative heteroskedasticity. Journal of Econometrics $8,227-236$.

Grier, K.G., Tullock, G., 1989. An empirical analysis of cross-national economic growth, 1951-1980. Journal of Monetary Economics 24, 259-279.

Harms, P., Ursprung, H.W., 2002. Do civil and political repression really boost foreign direct investments? Economic Inquiry 40, 651-663.

Hausman, J., 1978. Specification tests in econometrics. Econometrica 46, 1251-1271.

Hausman, J., Taylor, W., 1981. Panel data and unobservable individual effects. Econometrica 49, 1377-1398.

Head, K., Ries, J., 2008. FDI as an outcome of the market for corporate control: Theory and evidence. Journal of International Economics 74, 2-20.

Henisz, W.J., 2000. The institutional environment for economic growth. Economics and Politics 12, 1-31.

Hensel, C.R., Ziemba, W.T., 1995. United States investment returns during democratic and republican administrations, 1928-1993. Financial Analysts Journal 51, March-April, 61-69.

Hibbs, D.A. Jr., 1977. Political parties and macroeconomic policy. American Political Science Review 71, 1467-1487.

IDEA, 2011. IDEA Voter Turnout Database, available at: www.idea.int/vt/index.cfm, last accessed $10^{\text {th }}$ September, 2011.

IFES, 2011. Election Guide, Database, available at: www.electionguide.org, last accessed $12^{\text {th }}$ September, 2011.

Jakobsen, J., de Soysa, I., 2006. Do foreign investors punish democracy? Theory and empirics, 1984-2001. Kyklos 59, 383-410.

Jensen, N.M., 2003. Democratic governance and multinational corporations: Political regimes and inflows of foreign direct investment. International Organization 57, 587-616. 
Johnson, R.R., Chittenden, W., Jensen, G., 1999. Presidential politics, stocks, bonds, bills and inflation. Journal of Portfolio Management 26, Fall, 27-31.

Julio, B., Yook, Y., 2012. Political uncertainty and corporate investment cycles. Journal of Finance 67, 45-83.

Ledyaeva, S., Karhunen, P., Kosonen, R., 2013. Birds of feather: Evidence on commonality of corruption and democracy in the origin and location of foreign investment in Russian regions. European Journal of Political Economy 32, 1-25.

Landau, D., 1983. Government expenditure and economic growth: A cross-country study. Southern Economic Journal 49, 783-792.

Laubach, T., 2009. New evidence on the interest rate effects of budget deficits and debt. Journal of the European Economic Association 4, 858-885.

Levin, A., Lin, C.F., Chu, C.S.J., 2002. Unit root tests in panel data: Asymptotic and finite sample properties. Journal of Econometrics 108, 1-24.

Li, Q., Resnick, A., 2003. Reversals of fortunes: Democratic institutions and foreign direct investment inflows to developing countries. International Organization 57, 175-211.

Maddala, G.S., Wu, S., 1999. A comparative study of unit root tests with panel data and a new simple test. Oxford Bulletin of Economics and Statistics 61, 631-652.

Markusen, J.R., 1983. Factor movements and commodity trade as complements. Journal of International Economics 14, 341-356.

Mudambi, R., Navarra, P., 2003. Political tradition, political risk and foreign direct investment in Italy. Management International Review 43, 247-265.

Mundell, R.A., 1957. International trade and factor mobility. American Economic Review 47, 321-335.

OECD, 2008. The new OECD benchmark definition of foreign direct investment enters into force. OECD Investment News, June 2008, No. 7, downloadable at: http://www.oecd.org/dataoecd/18/28/40887916.pdf, last accessed $1^{\text {st }}$ November 2011.

OECD, 2011. Main Economic Indicators (Edition: October 2011). ESDS International, University of Manchester.

Oneal, J.R., 1994. The affinity of foreign investors for authoritarian regimes. Political Research Quarterly 47, 565-588.

Pinto, P.M., Pinto, S.M., 2008. The politics of investment partisanship and the sectoral allocation of foreign direct investment. Economics and Politics 20, 216-254.

Regan, P.M., Frank, R.W., Clark, D.H., 2009. New datasets on political institutions and elections, 1972-2005. Conflict Management and Peace Science 26, 286-304.

Santa-Clara, P., Valkanov, R., 2003. The presidential puzzle: Political cycles and the stock market. Journal of Finance 58, 1841-1872. 
Schneider, F., Frey, B.S., 1985. Economic and political determinants of foreign direct investment. World Development 13, 161-175.

Sims, C.A., 1994. A simple model for study of the determination of the price level and the interaction of monetary and fiscal policy. Economic Theory 4, 381-399.

Thompson, S.B., 2011. Simple formulas for standard errors that cluster by both firm and time. Journal of Financial Economics 99, 1-10.

White, H., 1980. A heteroskedasticity-consistent covariance matrix estimator and a direct test for heteroskedasticity. Econometrica 48, 817-38.

World Bank, 2011. World Development Indicators (Edition: September 2011). ESDS International, University of Manchester. 
Table I

Variables Used and Data Sources

Variable

Dependent Variable

FDI Inflow

Foreign direct investment, net inflows (\% of GDP)

Explanatory (Political) Variables

Government_Spending

General government final consumption expenditure ( $\%$ of GDP)

Military_Expenditure

Military expenditure (\% of GDP)

Non-Military_Expenditure

Right

Center

Presidential

Years_In_Power

Party_Age

All_Houses

\section{Control Variables}

Openness

GDP_Growth

Inflation

\section{Definition} centrist and zero otherwise. system and zero otherwise. and first opposition party (in years) controls all houses with lawmaking power and zero otherwise.

Growth rate in Consumer Price Index (all items)
Data Source

Derived variable equal to Government_Spending - Military_Expenditure

Dummy variable. Takes a value of one when the party of the executive is conservative, Christian democratic, or right-wing and zero otherwise.

Dummy variable. Takes a value of one when the party of the executive is

Dummy variable. Takes a value of one for countries with presidential

Length of time that the party of executive has been in office (in years)

Average ages of the first government party, the second government party

Dummy variable. Takes a value of one when the party of the executive

The sum of imports and exports of goods and services (\% of GDP)

GDP per capita growth based on constant local currency (annual \%)
World Development Indicators

World Development Indicators

World Development Indicators

World Development Indicators

Database of Political Institutions

Database of Political Institutions

Database of Political Institutions

Database of Political Institutions

Database of Political Institutions

Database of Political Institutions

World Development Indicators

World Development Indicators

Main Economic Indicators 
Table II

\section{Summary Statistics}

\begin{tabular}{|c|c|c|c|c|c|c|}
\hline Variable & $\begin{array}{c}\text { Number of } \\
\text { Observations }\end{array}$ & Mean & $\begin{array}{l}\text { Standard } \\
\text { Deviation }\end{array}$ & $25^{\text {th }}$ Percentile & Median & $75^{\text {th }}$ Percentile \\
\hline \multicolumn{7}{|l|}{ Dependent Variable } \\
\hline FDI_Inflow & 1046 & 2.5400 & 5.2626 & 0.4247 & 1.2262 & 2.8814 \\
\hline \multicolumn{7}{|c|}{ Explanatory (Political) Variables } \\
\hline Government_Spending & 1086 & 18.5692 & 5.2495 & 14.9419 & 18.8603 & 21.6833 \\
\hline Military_Expenditure & 688 & 2.2314 & 1.6992 & 1.3058 & 1.8717 & 2.5259 \\
\hline Non-Military_Expenditure & 684 & 16.3609 & 4.6982 & 12.8028 & 17.0976 & 19.2528 \\
\hline Right & 1188 & 0.4599 & 0.4986 & 0.0000 & 0.0000 & 1.0000 \\
\hline Center & 1188 & 0.0878 & 0.2832 & 0.0000 & 0.0000 & 0.0000 \\
\hline Presidential & 1188 & 0.1496 & 0.3568 & 0.0000 & 0.0000 & 0.0000 \\
\hline Years_In_Power & 1026 & 9.0702 & 11.8453 & 2.0000 & 5.0000 & 9.0000 \\
\hline Party_Age & 1010 & 52.6550 & 35.0558 & 23.5417 & 51.6250 & 72.6667 \\
\hline All_Houses & 1071 & 0.2810 & 0.4497 & 0.0000 & 0.0000 & 1.0000 \\
\hline \multicolumn{7}{|l|}{ Control Variables } \\
\hline Openness & 1079 & 70.0134 & 34.4076 & 47.8407 & 63.0941 & 82.5233 \\
\hline GDP_Growth & 1091 & 2.0341 & 3.2083 & 0.5922 & 2.2106 & 3.7589 \\
\hline Inflation & 1102 & 13.5132 & 52.1602 & 2.2125 & 4.1785 & 10.1271 \\
\hline
\end{tabular}




\section{Table III}

\section{Determinants of FDI Inflows}

Variable definitions can be found in Table I. Standard errors in the pooled OLS estimation are based on White (1980) heteroskedasticity-consistent estimation approach. Models (3) and (4) are fixed effect panels fitted using a feasible GLS method, which takes account of heteroskedasticity by applying cross-section weights. The last two columns report coefficient estimates for two-way fixed effect models that include dummies for both countries and years. To conserve space, fixed effects are not reported. The table also shows the number of observations used to estimate each of the regressions, the unweighted R-squared measure, as well as tests for three null hypotheses: a) the independent variables have jointly no impact on FDI, b) political factors do not influence the dependent variable, c) the fixed effects in the panel models are redundant. Standard errors are given in parentheses. $^{* * *},{ }^{* *},{ }^{*}$ denote statistical significance at $1 \%, 5 \%$ and $10 \%$, respectively.

\begin{tabular}{|c|c|c|c|c|c|c|}
\hline & \multicolumn{2}{|c|}{ Pooled OLS } & \multicolumn{2}{|c|}{ Fixed Effect Panel } & \multicolumn{2}{|c|}{$\begin{array}{c}\text { Two-Way Fixed } \\
\text { Effect Panel }\end{array}$} \\
\hline & (1) & (2) & (3) & (4) & (5) & (6) \\
\hline Intercept & $\begin{array}{l}-1.1238^{*} \\
(0.6514)\end{array}$ & $\begin{array}{l}-1.2649 \\
(1.0486)\end{array}$ & & & & \\
\hline Government_Spending & $\begin{array}{l}-0.0856^{* *} \\
(0.0385)\end{array}$ & & $\begin{array}{l}-0.1425^{* * *} \\
(0.0301)\end{array}$ & & $\begin{array}{l}-0.1615^{* *} \\
(0.0800)\end{array}$ & \\
\hline Military_Expenditure & & $\begin{array}{l}-0.2190^{* * *} \\
(0.0635)\end{array}$ & & $\begin{array}{l}-0.7166^{* * *} \\
(0.1003)\end{array}$ & & $\begin{array}{l}-0.5741^{* * *} \\
(0.1886)\end{array}$ \\
\hline Non-Military_Expenditure & & $\begin{array}{l}-0.0669 \\
(0.0624)\end{array}$ & & $\begin{array}{l}-0.2709^{* * *} \\
(0.0478)\end{array}$ & & $\begin{array}{l}-0.2827^{* *} \\
(0.1426)\end{array}$ \\
\hline Right & $\begin{array}{c}0.1154 \\
(0.3193)\end{array}$ & $\begin{array}{c}0.5321 \\
(0.4998)\end{array}$ & $\begin{array}{l}-0.0943 \\
(0.1032)\end{array}$ & $\begin{array}{l}-0.1187 \\
(0.1347)\end{array}$ & $\begin{array}{l}-0.3992^{*} \\
(0.2199)\end{array}$ & $\begin{array}{l}-0.4640^{*} \\
(0.2801)\end{array}$ \\
\hline Center & $\begin{array}{l}-0.9739 \\
(0.6055)\end{array}$ & $\begin{array}{l}-2.1886^{* * *} \\
(0.7365)\end{array}$ & $\begin{array}{c}-0.3372^{* *} \\
(0.1485)\end{array}$ & $\begin{array}{c}-0.4083^{*} \\
(0.2347)\end{array}$ & $\begin{array}{l}-0.0069 \\
(0.5524)\end{array}$ & $\begin{array}{l}-0.5631 \\
(0.5292)\end{array}$ \\
\hline Presidential & $\begin{array}{c}0.7377^{* * *} \\
(0.2368)\end{array}$ & $\begin{array}{c}0.7691^{* *} \\
(0.3562)\end{array}$ & & & & \\
\hline
\end{tabular}




\begin{tabular}{lcccccc} 
& & & \\
Years_In_Power & -0.0092 & $-0.0304^{* * *}$ & $-0.0118^{* * *}$ & $-0.0228^{* * *}$ & $-0.0491^{*}$ & $-0.1003^{* * *}$ \\
& $(0.0072)$ & $(0.0116)$ & $(0.0040)$ & $(0.0067)$ & $(0.0265)$ & $(0.0377)$ \\
Party_Age & $0.0128^{* * *}$ & $0.0153^{* * *}$ & $0.0117^{* * *}$ & $0.0130^{* * *}$ & 0.0110 & $0.0188^{* *}$ \\
& $(0.0040)$ & $(0.0048)$ & $(0.0029)$ & $(0.0038)$ & $(0.0070)$ & $(0.0086)$ \\
All_Houses & $0.3775^{* *}$ & 0.2142 & 0.1785 & $0.3358^{* *}$ & $0.5123^{*}$ & $0.8867^{* *}$ \\
& $(0.1638)$ & $(0.2212)$ & $(0.1093)$ & $(0.1348)$ & $(0.3058)$ & $(0.3741)$ \\
Openness & $0.0647^{* * *}$ & $0.0702^{* * *}$ & $0.0693^{* * *}$ & $0.0564^{* * *}$ & $0.0845^{* * *}$ & $0.1052^{* * *}$ \\
& $(0.0112)$ & $(0.0133)$ & $(0.0064)$ & $(0.0077)$ & $(0.0224)$ & $(0.0312)$ \\
GDP_Growth & 0.0524 & 0.0937 & 0.0037 & 0.0240 & 0.0853 & 0.0651 \\
& $(0.0462)$ & $(0.0641)$ & $(0.0165)$ & $(0.0237)$ & $(0.0542)$ & $(0.0768)$ \\
Inflation & $-0.0138^{* * *}$ & $-0.0143^{* *}$ & $-0.0112^{* * *}$ & -0.0003 & 0.0017 & 0.0099 \\
& $(0.0034)$ & $(0.0065)$ & $(0.0028)$ & $(0.0036)$ & $(0.0034)$ & $(0.0093)$ \\
\hline Number of Observations & 900 & 608 & 900 & 608 & 900 & 608 \\
R-squared (non-weighted) & 0.1641 & 0.1865 & 0.2493 & 0.3126 & 0.3537 & 0.4047 \\
F-statistic (regression) & 17.4479 & 12.4190 & 19.3048 & 16.3491 & 6.1924 & 6.0861 \\
$p$-value & 0.0000 & 0.0000 & 0.0000 & 0.0000 & 0.0000 & 0.0000 \\
F-statistic (insignificant political effects) & 8.8086 & 5.6764 & 5.4370 & 10.1081 & 2.1299 & 3.8356 \\
$p$-value & 0.0000 & 0.0000 & 0.0000 & 0.0000 & 0.0478 & 0.0004 \\
F-statistic (redundant fixed effects) & & & 11.9167 & 11.3843 & 3.8240 & 3.9528 \\
$p$-value & & & 0.0000 & 0.0000 & 0.0000 & 0.0000 \\
\hline
\end{tabular}




\section{Table IV}

\section{FDI Regressions based on a Democratic Sample}

The regressions reported in this table are based on a sample, which excludes non-democratic periods. Variable definitions can be found in Table I. Standard errors in the pooled OLS estimation are based on White (1980) heteroskedasticity-consistent estimation approach. Models (3) and (4) are fixed effect panels fitted using a feasible GLS method, which takes account of heteroskedasticity by applying cross-section weights. The last two columns report coefficient estimates for two-way fixed effect models that include dummies for both countries and years. To conserve space, fixed effects are not reported. The table also shows the number of observations used to estimate each of the regressions, the unweighted R-squared measure, as well as tests for three null hypotheses: a) the independent variables have jointly no impact on FDI, b) political factors do not influence the dependent variable, c) the fixed effects in the panel models are redundant. Standard errors are given in parentheses. ${ }^{* * *},{ }^{* *},{ }^{*}$ denote statistical significance at $1 \%, 5 \%$ and $10 \%$, respectively.

\begin{tabular}{|c|c|c|c|c|c|c|}
\hline & \multicolumn{2}{|c|}{ Pooled OLS } & \multicolumn{2}{|c|}{ Fixed Effect Panel } & \multicolumn{2}{|c|}{$\begin{array}{c}\text { Two-Way Fixed } \\
\text { Effect Panel }\end{array}$} \\
\hline & (1) & (2) & (3) & (4) & (5) & (6) \\
\hline Intercept & $\begin{array}{l}-0.9717 \\
(0.6366)\end{array}$ & $\begin{array}{l}-0.9027 \\
(0.9960)\end{array}$ & & & & \\
\hline Government_Spending & $\begin{array}{l}-0.0862^{* *} \\
(0.0386)\end{array}$ & & $\begin{array}{l}-0.1576^{* * *} \\
(0.0325)\end{array}$ & & $\begin{array}{l}-0.1441^{*} \\
(0.0813)\end{array}$ & \\
\hline Military_Expenditure & & $\begin{array}{l}-0.2106^{* * *} \\
(0.0604)\end{array}$ & & $\begin{array}{l}-0.7231^{* * *} \\
(0.1021)\end{array}$ & & $\begin{array}{l}-0.5083^{* * *} \\
(0.1840)\end{array}$ \\
\hline Non-Military_Expenditure & & $\begin{array}{l}-0.0753 \\
(0.0640)\end{array}$ & & $\begin{array}{l}-0.2921^{* * *} \\
(0.0501)\end{array}$ & & $\begin{array}{l}-0.2893^{* *} \\
(0.1447)\end{array}$ \\
\hline Right & $\begin{array}{c}0.2425 \\
(0.3616)\end{array}$ & $\begin{array}{c}0.6816 \\
(0.5533)\end{array}$ & $\begin{array}{c}-0.0376 \\
(0.1089)\end{array}$ & $\begin{array}{l}-0.0963 \\
(0.1372)\end{array}$ & $\begin{array}{l}-0.2368 \\
(0.2487)\end{array}$ & $\begin{array}{l}-0.2519 \\
(0.3122)\end{array}$ \\
\hline Center & $\begin{array}{l}-0.8896 \\
(0.5961)\end{array}$ & $\begin{array}{l}-2.0917^{* * *} \\
(0.7241)\end{array}$ & $\begin{array}{l}-0.4028^{* *} \\
(0.1597)\end{array}$ & $\begin{array}{l}-0.4484^{*} \\
(0.2322)\end{array}$ & $\begin{array}{c}0.1474 \\
(0.5704)\end{array}$ & $\begin{array}{l}-0.3404 \\
(0.5693)\end{array}$ \\
\hline Presidential & $0.4963^{*}$ & 0.4723 & & & & \\
\hline
\end{tabular}




\begin{tabular}{lcccccc} 
& $(0.2757)$ & $(0.3940)$ & & & & \\
& $-0.0321^{*}$ & $-0.0741^{* *}$ & $-0.0158^{* * *}$ & $-0.0284^{* *}$ & $-0.0839^{* *}$ & $-0.1629^{* *}$ \\
Years_In_Power & $(0.0185)$ & $(0.0317)$ & $(0.0053)$ & $(0.0118)$ & $(0.0407)$ & $(0.0644)$ \\
& $0.0124^{* * *}$ & $0.0159^{* * *}$ & $0.0140^{* * *}$ & $0.0137^{* * *}$ & 0.0121 & $0.0212^{* *}$ \\
Party_Age & $(0.0041)$ & $(0.0051)$ & $(0.0032)$ & $(0.0039)$ & $(0.0076)$ & $(0.0091)$ \\
& $0.3474^{*}$ & 0.0832 & 0.0869 & $0.2889^{* *}$ & 0.1821 & $0.5937^{*}$ \\
All_Houses & $(0.1838)$ & $(0.2373)$ & $(0.1207)$ & $(0.1398)$ & $(0.2759)$ & $(0.3206)$ \\
& $0.0643^{* * *}$ & $0.0703^{* * *}$ & $0.0770^{* * *}$ & $0.0580^{* * *}$ & $0.0927^{* * *}$ & $0.1019^{* * *}$ \\
Openness & $(0.0111)$ & $(0.0133)$ & $(0.0076)$ & $(0.0079)$ & $(0.0248)$ & $(0.0309)$ \\
& 0.0759 & 0.1032 & 0.0091 & 0.0238 & 0.0974 & 0.0804 \\
GDP_Growth & $(0.0502)$ & $(0.0664)$ & $(0.0178)$ & $(0.0243)$ & $(0.0609)$ & $(0.0809)$ \\
& $-0.0169^{* * *}$ & $-0.0213^{* * *}$ & $-0.0124^{* * *}$ & -0.0004 & -0.0017 & 0.0019 \\
Inflation & $(0.0049)$ & $(0.0068)$ & $(0.0036)$ & $(0.0038)$ & $(0.0036)$ & $(0.0078)$ \\
\hline Number of Observations & 870 & 596 & 870 & 596 & 870 & 596 \\
R-squared (non-weighted) & 0.1654 & 0.1897 & 0.2534 & 0.3145 & 0.3594 & 0.4135 \\
F-statistic (regression) & 17.0238 & 12.4296 & 16.9642 & 15.0818 & 6.1182 & 6.1711 \\
$p$-value & 0.0000 & 0.0000 & 0.0000 & 0.0000 & 0.0000 & 0.0000 \\
F-statistic (insignificant political effects) & 5.8311 & 5.1534 & 5.9619 & 9.9606 & 1.9369 & 3.6617 \\
$p$-value & 0.0000 & 0.0000 & 0.0000 & 0.0000 & 0.0724 & 0.0007 \\
F-statistic (redundant fixed effects) & & & 10.7292 & 11.0841 & 3.7822 & 4.0042 \\
$p$-value & & & 0.0000 & 0.0000 & 0.0000 & 0.0000 \\
\hline
\end{tabular}

